\title{
Heterogeneity of Indonesian primary school students' mathematical critical thinking skills through problem- based learning: A meta-analysis
}

\author{
Trisna Nugraha ${ }^{1}$, Suparman ${ }^{1}$ \\ ${ }^{1}$ Universitas Pendidikan Indonesia \\ $\square$ risna.nugraha@upi.edu*
}

\section{Article Information}

Submitted August, 08, 2021

Revised August, 262021

Accepted Sept 01, 2021

\section{Keywords}

Heterogeneity;

Mathematical Critical Thinking

Skills;

Meta-Analysis;

Problem-Based Learning.

\begin{abstract}
The synthesis of some empirical researches revealed that the implementation of problem-based learning (PBL) has a heterogeneous effect size on the mathematical critical thinking skills (MCTS) of primary school students in Indonesia. However, it seems that no researches were investigating the causative factors of the heterogeneity of primary students' MCTS through PBL. Therefore, this meta-analysis research was employed to examine three potential factors that were PBL class capacity, PBL treatment duration, and mathematics topic predicted as the causative factors of the heterogeneity of primary students' MCTS. The Q Cochrane test by using the Comprehensive Meta-Analysis (CMA) application was used to examine these potential factors. The synthesis of ten primary studies published in 2015 - 2020 and indexed by Scopus, Google Scholar, Sinta, and Web of Science, showed that PBL treatment duration and mathematics topic were the significant factors causing the heterogeneity of primary students' MCTS. However, PBL class capacity was not a significant factor causing the heterogeneity of primary students' MCTS. Thus, primary school mathematics teachers should consider PBL treatment duration established and mathematics topics selected in cultivating primary students' MCTS by implementing PBL.
\end{abstract}

\section{INTRODUCTION}

Hoax information, information that is not justified in its truth and trustworthiness (Epafras et al., 2019), is one of the negative effects of information abundance in the $21^{\text {st }}$ - century in which someone deploys it to other individuals without the process of analyzing, filtering, and clarifying. The deployment of hoax information is conducted by some individuals because they have low critical thinking skills in evaluating the truth of the information (Apriyani et al., 2019). Critical thinking skill, a complex and essential skill of the higher-order thinking process, involves some accurate and precise evaluation processes of information such as analyzing, filtering, clarifying, interpreting, and explaining (Sanders, 2016). Since it is one of the $21^{\text {st }}$ - century skills (Sanabria \& Arámburo-Lizárraga, 2017; Silber-Varod et al., 2019), mathematics learning in the $21^{\text {st }}$ century should be designed so that students can cultivate their mathematical critical thinking skills (MCTS).

To cultivate students' MCTS, some Indonesian mathematics teachers in primary school select problem-based learning (PBL) as one of the alternative mathematics learnings. PBL, a learning approach, begins a certain topic with complex problems (Suparman, Juandi, \& Herman, 2021). It is selected as one of the best solutions because its design can accommodate the enhancement of learning quality by developing students' critical thinking and problem-solving skills (Suparman, Juandi, \& Tamur, 2021b; Yew \& Goh, 2016). Also, it can create students as critical individuals who can analyze, verify, and justify the truth and validity of information so that they can employ the information accurately and correctly (Du et al., 2013; Nargundkar et al., 
2014; Neber \& Neuhaus, 2013). Therefore, primary mathematics teachers implement it to increase students' low MCTS.

Several reports related to the PBL implementation on the primary school students' MCTS in Indonesia revealed that the PBL implementation had a strong effect on the students' MCTS (Ahdhianto et al., 2020; Alnita \& Arifin, 2017; Buana et al., 2020; Pramestika et al., 2020; Soraya et al., 2018; Suprapto et al., 2020; Umar et al., 2020). On the other side, some similar reports revealed that the PBL implementation had a moderate effect on the students' MCTS (Haerani et al., 2019; Karyono \& Subhananto, 2015; Primayanti et al., 2019). The discovery of these reports show that the effect of the implementation of PBL on the primary students' MCTS is heterogeneous. Unfortunately, the factors causing the heterogeneity of the primary students' MCTS through PBL have not been found and reported comprehensively. Meanwhile, clear and accurate information regarding the causative factors creating the heterogeneity of students' MCTS through PBL is required by mathematics teachers in primary school specifically. They need some information such as on what class capacity, how long the treatment duration, and on what mathematics topic, the PBL implementation is most effective in cultivating primary students' MCTS.

A meta-analysis, one of the best researches, can provide clear and accurate information about the problem. Some meta-analysis researches regarding the investigation of heterogeneous students' MCTS through PBL have been carried out by some researchers (Suparman et al., 2021; Suparman, Juandi, \& Tamur, 2021a, 2021c; Yohannes et al., 2020). However, they study heterogeneity of Indonesian high and vocational school students' MCTS (Yohannes et al., 2020), and heterogeneity of students' MCTS in the various education level in Indonesia (Suparman et al., 2021; Suparman, Juandi, \& Tamur, 2021a, 2021c). Meanwhile, this research focuses on the heterogeneity of Indonesian primary school students' MCTS. Therefore, this recent research aims to examine three potential factors, namely PBL class capacity, PBL treatment duration, and mathematics topic predicted as the causative factors of the heterogeneity of students' MCTS.

\section{METHODS}

This research employed meta-analysis by selecting the random effect model. A meta-analysis, a series of statistical methods, synthesized some similar quantitative primary studies to provide summarization, estimation, and evaluation regarding the effect size of one variable to another variable (Borenstein et al., 2009). Cooper et al. (2013) presented that there were seven steps to carry out a meta-analysis research. These steps are presented in Figure 1.

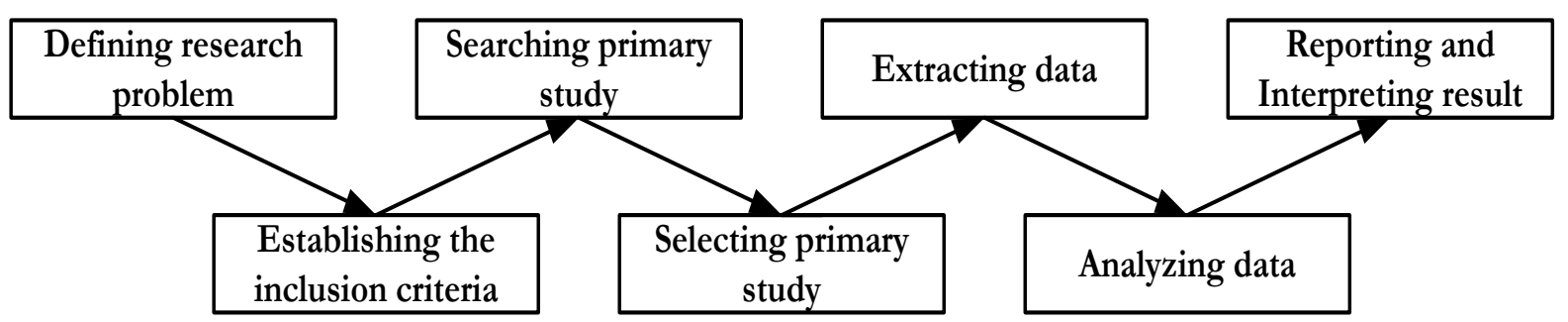

Figure 1. The Steps of Meta-Analysis

For this part, we only explained the five steps of the meta-analysis research. Firstly, we established some inclusion criteria. The inclusion criteria referred to PICOS (Population, Intervention, Comparator, Outcome, and Study Design) approach (Liberati et al., 2009). The inclusion criteria of this research were: (1) every study provided completely statistical data such 
as t-value, p-value, sample size (N), standard deviation (SD), and mean; (2) every study was journaled or proceeding articles published in 2015 - 2020 and indexed by Sinta, Google Scholar, Scopus, and Web of Science; (3) study design of the selected study was quasi-experiment research with the posttest only control group design; (4) outcome of the selected study was MCTS; (5) comparator of the selected study was conventional learning (CL); (6) intervention of the selected study was PBL, and (7) population of the selected study was primary school students in Indonesia. Primary studies that were not suitable to the inclusion criteria were excluded from this research.

Secondly, we searched for primary studies. Semantic Scholar and Google Scholar were search engines used to find primary studies. Also, we combined some keywords such as "problem-based learning and mathematical critical thinking skills" or "problem-based learning and mathematical critical thinking abilities" to ease the search for primary study.

Thirdly, we selected every primary study. Liberati et al. (2009) revealed that there were four steps to select the primary studies, namely: (1) identification; (2) screening; (3) eligibility; and (4) inclusion. We selected every primary study based on its title in the identification step. Also, we selected every primary study based on its abstract in the screening step. In addition, we selected every primary study based on the inclusion criteria in the eligibility step. Lastly, we selected every primary study based on the publication bias test in the inclusion step. The unselected primary studies were excluded from this research.

Fourthly, we extracted numerical data and categorical data from every primary study to the coding sheet. To complete the missing numerical and categorical data in the coding sheet, we communicated to the authors by using e-mail. In addition, we involved two coders to verify that the results of data extraction were valid and reliable (Vevea et al., 2019). To measure the consistency of the data extraction results conducted by these coders, we employed Cohen's Kappa test (McHugh, 2012). Furthermore, these Cohen's Kappa values were interpreted as $\kappa=$ $0.00-0.20$ (none), $\kappa=0.21-0.39$ (minimal), $\kappa=0.40-0.59$ (weak), $\kappa=0.60-0.79$ (moderate), $\kappa=0.80-0.90$ (strong), and $\kappa>0.90$ (almost perfect) (McHugh, 2012). The calculation of Cohen's Kappa test used SPSS software.

Fifthly, we analyzed data. To measure the effect size, we used Hedge's equation (Borenstein et al., 2009), because it accommodated a relatively small sample size (Lipsey \& Wilson, 2001). These effect size values were categorized as $g=0.00-0.20$ (weak), $g=0.21-$ 0.50 (modest), $g=0.51-1.00$ (moderate), and $g>1.00$ (strong) (Cohen et al., 2018). Also, we conducted publication bias analysis by using Rosenthal's FSN test to justify that the effect size data was resistant to publication bias (Rothstein et al., 2005) and sensitivity analysis by using the "one study removed" tool in CMA software to justify that the effect size data were normal and stable (Bernard et al., 2014). In addition, we employed the $Z$ test to justify the significance of PBL implementation on the primary students' MCTS in every factor (Borenstein et al., 2009). Furthermore, we carried out heterogeneity analysis by using the Q Cochrane test to justify the significance of PBL class capacity, PBL treatment duration, mathematics topic, and students' demography as the causative factors of the heterogeneity of primary students' MCTS (Higgins et al., 2003). All of the data analysis used CMA application. 


\section{RESULTS AND DISCUSSION}

\section{Search and Selection of Primary Studies}

The search process using some keywords such as "mathematical critical thinking skills and problem-based learning" or "mathematical critical thinking abilities and problem-based learning", we found 40 primary studies titles from Google Scholar and 50 primary study titles from Semantic Scholar. Furthermore, the selection process of primary studies is presented in Figure 2.

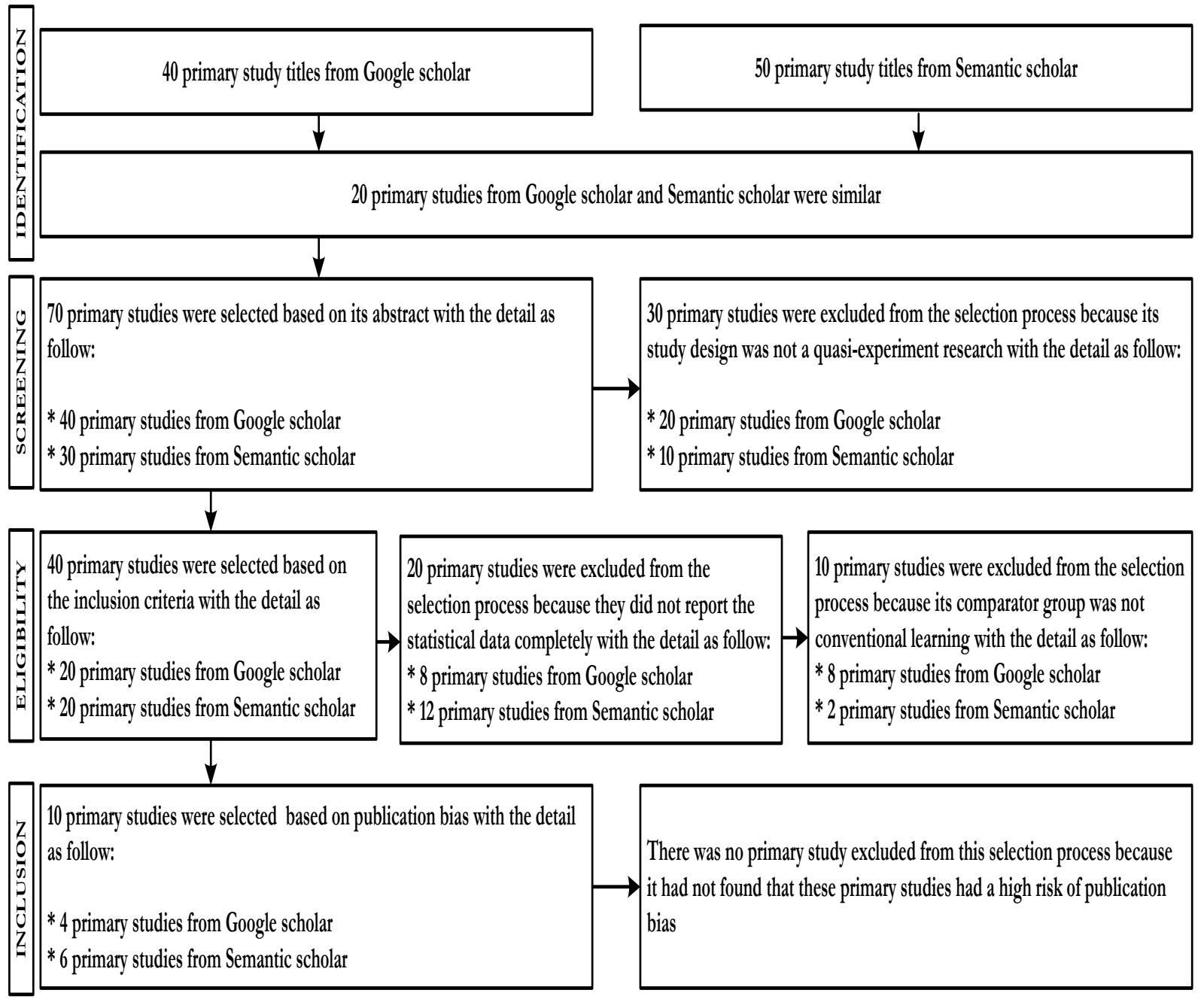

Figure 2. The Selection Process of Primary Studies

Based on the results of the primary study selection process, we established ten primary studies consisting of four primary studies from Google Scholar (Haerani et al., 2019; Karyono \& Subhananto, 2015; Primayanti et al., 2019; Soraya et al., 2018) and six primary studies from Semantic Scholar (Ahdhianto et al., 2020; Alnita \& Arifin, 2017; Buana et al., 2020; Pramestika et al., 2020; Suprapto et al., 2020; Umar et al., 2020) to be used as the data in this research.

\section{Data Extraction}

The results of numerical data extraction such as t-value, $\mathrm{p}$-value, $\mathrm{SD}, \mathrm{N}$, and mean are presented in Table 1. 
Table 1. The Results of Numerical Data Extraction

\begin{tabular}{lcccccccc}
\hline \multirow{2}{*}{\multicolumn{1}{c}{ Citation }} & \multicolumn{7}{c}{ Numerical Data } \\
\cline { 2 - 7 } & \multicolumn{7}{c}{ PBL } & \multicolumn{5}{c}{ CL } & \multirow{2}{*}{ t-value } & \multirow{2}{*}{ P-value } \\
\cline { 2 - 7 } & Mean & SD & N & Mean & SD & N & & \\
\hline (Ahdhianto et al., 2020) & 76.74 & 10.90 & 39 & 64.83 & 11.48 & 39 & \\
(Buana et al., 2020) & 39.04 & 7.45 & 23 & 29.52 & 5.79 & 23 & \\
(Alnita \& Arifin, 2017) & 70.03 & 10.19 & 30 & 52.73 & 8.92 & 30 & \\
(Umar et al., 2020) & 51.00 & 9.80 & 36 & 36.00 & 6.80 & 38 & & \\
(Pramestika et al., 2020) & 81.47 & 17.24 & 32 & 64.17 & 16.60 & 30 & & \\
(Suprapto et al., 2020) & & & 27 & & & 28 & -14.76 & \\
(Haerani et al., 2019) & & & 28 & & & 28 & 2.799 & \\
(Karyono \& Subhananto, 2015) & & & 45 & & & 45 & 2.654 & \\
(Primayanti et al., 2019) & & & 25 & & & 30 & & 0.025 \\
(Soraya et al., 2018) & & & 27 & & & 31 & 0.000 \\
\hline
\end{tabular}

The results of categorical data extraction such as PBL class capacity, PBL treatment duration, mathematics topic, indexer, and publication type are presented in Table 2.

Table 2. The Results of Categorical Data Extraction

\begin{tabular}{|c|c|c|c|c|c|}
\hline \multirow[b]{2}{*}{ Citation } & \multicolumn{3}{|c|}{ Potential Factor } & \multirow[b]{2}{*}{ Indexer } & \multirow[b]{2}{*}{$\begin{array}{l}\text { Publication } \\
\text { Type }\end{array}$} \\
\hline & $\begin{array}{l}\text { PBL Class } \\
\text { Capacity }\end{array}$ & $\begin{array}{c}\text { PBL Treatment } \\
\text { Duration }\end{array}$ & $\begin{array}{l}\text { Math } \\
\text { Topic }\end{array}$ & & \\
\hline (Ahdhianto et al., 2020) & $>28$ & $3<\mathrm{t}<=6$ & Number & Scopus & Journal \\
\hline (Buana et al., 2020) & $<=28$ & $t>6$ & Number & Sinta & Journal \\
\hline (Alnita \& Arifin, 2017) & $>28$ & $1<t<=3$ & Geometry & Google Scholar & Journal \\
\hline (Umar et al., 2020) & $>28$ & $1<\mathrm{t}<=3$ & Geometry & Web of Science & Proceeding \\
\hline (Pramestika et al., 2020) & $>28$ & $3<\mathrm{t}<=6$ & Number & Sinta & Journal \\
\hline (Suprapto et al., 2020) & $<=28$ & $t>6$ & Geometry & Google Scholar & Journal \\
\hline (Haerani et al., 2019) & $<=28$ & $\mathrm{t}<=1$ & Statistics & Sinta & Journal \\
\hline $\begin{array}{l}\text { (Karyono \& Subhananto, } \\
\text { 2015) }\end{array}$ & $>28$ & $\mathrm{t}<=1$ & Statistics & Sinta & Journal \\
\hline (Primayanti et al., 2019) & $<=28$ & $\mathrm{t}<=1$ & Statistics & Sinta & Journal \\
\hline (Soraya et al., 2018) & $<=28$ & $1<t<=3$ & Number & Sinta & Journal \\
\hline
\end{tabular}

Table 3 reveals that the agreement level of two coders on the items in the coding sheet was moderate, strong, or almost perfect (McHugh, 2012). Moreover, these results showed that all of the significance values of Cohen's Kappa test in every item were less than 0.05 . These discoveries interpret that these coders significantly agree on the data extraction results of every item in the coding sheet (Cooper et al., 2013).

Table 3. The Results of the Cohen's Kappa Test

\begin{tabular}{lccc}
\hline \multicolumn{1}{c}{ Item } & Kappa Value & Agreement Level & Significance Value \\
\hline Citation & 0.814 & Strong & 0.023 \\
PBL group mean & 0.956 & Almost perfect & 0.004 \\
PBL group standard deviation & 0.916 & Almost perfect & 0.007 \\
PBL sample size & 0.934 & Almost perfect & 0.005 \\
CL group mean & 0.923 & Almost perfect & 0.006 \\
CL group standard deviation & 0.945 & Almost perfect & 0.004 \\
CL group sample size & 0.937 & Almost perfect & 0.005 \\
t-value & 0.967 & Almost perfect & 0.003 \\
p-value & 0.971 & Almost perfect & 0.002 \\
PBL class capacity & 0.854 & Strong & 0.021 \\
PBL treatment duration & 0.887 & Strong & 0.019 \\
Mathematics topic & 0.831 & Strong & 0.022 \\
Publication type & 0.861 & Strong & 0.020 \\
Publication year & 0.856 & Strong & 0.021 \\
Indexer & 0.799 & Moderate & 0.030
\end{tabular}




\begin{tabular}{lccc}
\hline \multicolumn{1}{c}{ Item } & Kappa Value & Agreement Level & Significance Value \\
\hline Search engine & 0.704 & Moderate & 0.034 \\
Journal and proceeding name & 0.761 & Moderate & 0.032 \\
Publisher & 0.724 & Moderate & 0.033 \\
Author's email & 0.754 & Moderate & 0.033 \\
Tracing link & 0.722 & Moderate & 0.033 \\
\hline
\end{tabular}

\section{Sensitivity and Publication Bias}

Rosenthal's FSN test was carried out to verify that the effect size collection was resistant to publication bias (Rothstein et al., 2005). The results of Rosenthal's FSN test are presented in Table 4.

Table 4. The Results of the FSN Test

\begin{tabular}{lr}
\hline & \\
\hline Z-value & Classic Fail-Safe N \\
P-value & 14.366 \\
FSN value & 0.000 \\
\hline
\end{tabular}

Table 2 reveals that the $\mathrm{p}$-value of the $\mathrm{Z}$ statistics was less than 0.05 . It interprets that the effect size collection is resistant to publication bias indication.

Sensitivity analysis was conducted to verify that the effect size collection was normal and stable from the change of sample size and effect size (Bernard et al., 2014). Analysis of effect size data using the "one study removed" tool in CMA software shows that the highest effect size was $g=1.447$ and the lowest effect size was $g=1.112$. Meanwhile, the overall effect size was $g$ $=1.350$. These discoveries indicate that the overall effect size is between the lowest effect size and the highest effect size. It interprets that the effect size collection is stable and normal from the change of sample size and effect size. Thus, the effect size collection is not sensitive.

\section{Heterogeneity of Primary School Students' MCTS Through PBL}

In this research, we investigated and examined four factors that were predicted as the causative factors of the heterogeneity of primary students' MCTS through PBL. These factors were PBL class capacity, PBL treatment duration, and mathematics topic. These factors were selected because they were substantive factors (Lipsey \& Wilson, 2001).

\section{PBL Class Capacity}

The factor of PBL class capacity consisted of two groups that were PBL class with a maximum capacity of 28 students and PBL class with a minimum capacity of 29 students (Indonesian Minister of education \& culture regulation No.17, 2017). The overall effect size of PBL on the students' MCTS based on PBL class capacity is presented in Figure 3. 


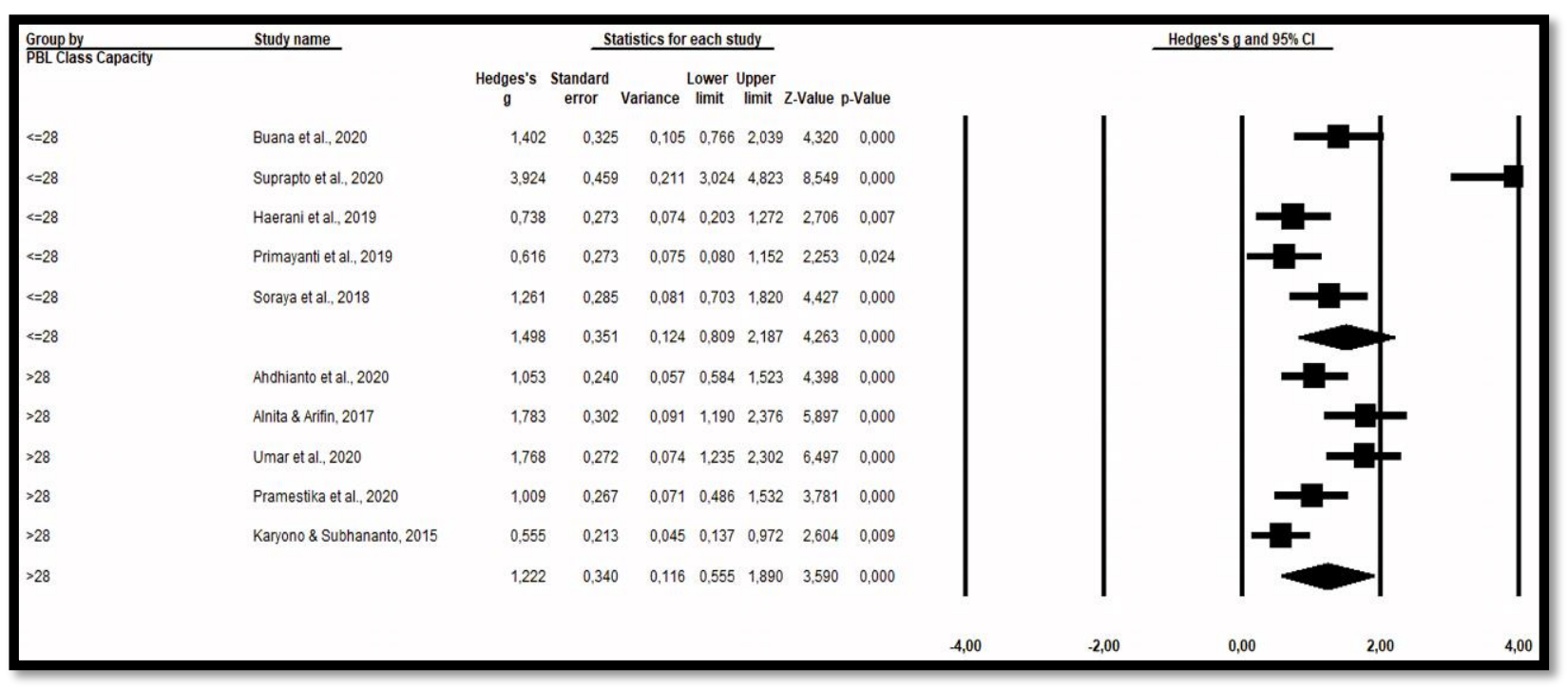

Figure 3. The Effect Size of PBL on the Primary Students' MCTS Based on PBL Class Capacity

Figure 3 reveals that the effect size of PBL on the students' MCTS in the class with a maximum capacity of 28 students was $g=1.498$ and it was categorized as a strong effect (Cohen et al., 2018). Meanwhile, the effect size of PBL on the students' MCTS in the class with a minimum capacity of 29 students was $g=1.222$ and it was categorized as a strong effect (Cohen et al., 2018). Moreover, the $\mathrm{p}$-values of the $\mathrm{Z}$ statistic in the class with a maximum capacity of 28 students and the class with a minimum capacity of 29 students were less than 0.05 . These discoveries interpret that the PBL implementation has a positive effect significantly on the primary students' MCTS in the class with a maximum capacity of 28 students and the class with a minimum capacity of 29 students. Also, some meta-analysis researches showed that the PBL implementation had a positive effect significantly on the students' MCTS in the class with a maximum capacity of 30 students and the class with a minimum capacity of 31 students (Suparman et al., 2021; Suparman, Juandi, \& Tamur, 2021a, 2021c; Yohannes et al., 2020). These reports give strict evidence that the PBL implementation in the class with a maximum capacity of 28 students and the class with a minimum capacity of 29 students is effective to cultivate students' MCTS.

The results of heterogeneity analysis based on the factor of PBL class capacity are presented in Table 5.

Table 5. The Results of the Q Cochrane Test of PBL Class Capacity Factor

\begin{tabular}{lccccc}
\hline \multirow{2}{*}{ PBL Class Capacity } & \multirow{2}{*}{ Studies Number } & \multirow{2}{*}{ Hedge's $g$} & \multicolumn{3}{c}{ Heterogeneity Analysis } \\
\cline { 4 - 6 } & 5 & 1.498 & Q-value & $\mathrm{df}(\mathrm{Q})$ & P-value \\
\hline $\mathrm{n} \leq 28$ students & 5 & 1.222 & 0.318 & 1 & \multirow{2}{*}{0.573} \\
$\mathrm{n}>28$ students & 5 &
\end{tabular}

Note: $\mathrm{n}=$ class capacity

Table 3 reveals that the $\mathrm{p}$-value of the Q Cochrane statistic was more than 0.05 . It indicates that PBL class capacity is not the significant factor causing the heterogeneity of students' MCTS. It means that the strong effect or the moderate effect of PBL on the students' MCTS are not affected by the factor of PBL class capacity. Also, Suparman et al. (2021a) and Yohannes et al. (2020) revealed that the heterogeneity of students' MCTS through PBL was not caused by the factor of PBL class capacity. In addition, the effect size of PBL on the students' MCTS in the class with a maximum capacity of 28 students was stronger than the effect size of PBL on the students' 
MCTS in the class with a minimum of 29 students. Moreover, several meta-analysis researches revealed that the PBL implementation in the class with a maximum capacity of 30 students was greater than the PBL implementation in the class with a minimum capacity of 31 students in enhancing students' MCTS (Suparman et al., 2021; Suparman, Juandi, \& Tamur, 2021a; Yohannes et al., 2020). These discoveries support that the PBL implementation in the class with a maximum capacity of 28 students is more effective than the implementation of PBL in the class with a minimum capacity of 29 students to cultivate primary students' MCTS.

\section{PBL Treatment Duration}

The factor of PBL treatment duration consisted of four groups that were $\mathrm{t} \leq 1,1<\mathrm{t} \leq 3,3<\mathrm{t}$ $\leq 6$, and $\mathrm{t}>6$ in which $\mathrm{t}$ was treatment duration in month unit (Indonesian Minister of Education and Culture Regulation No. 22, 2016). The overall effect size of PBL on the students' MCTS based on PBL treatment duration is presented in Figure 4.

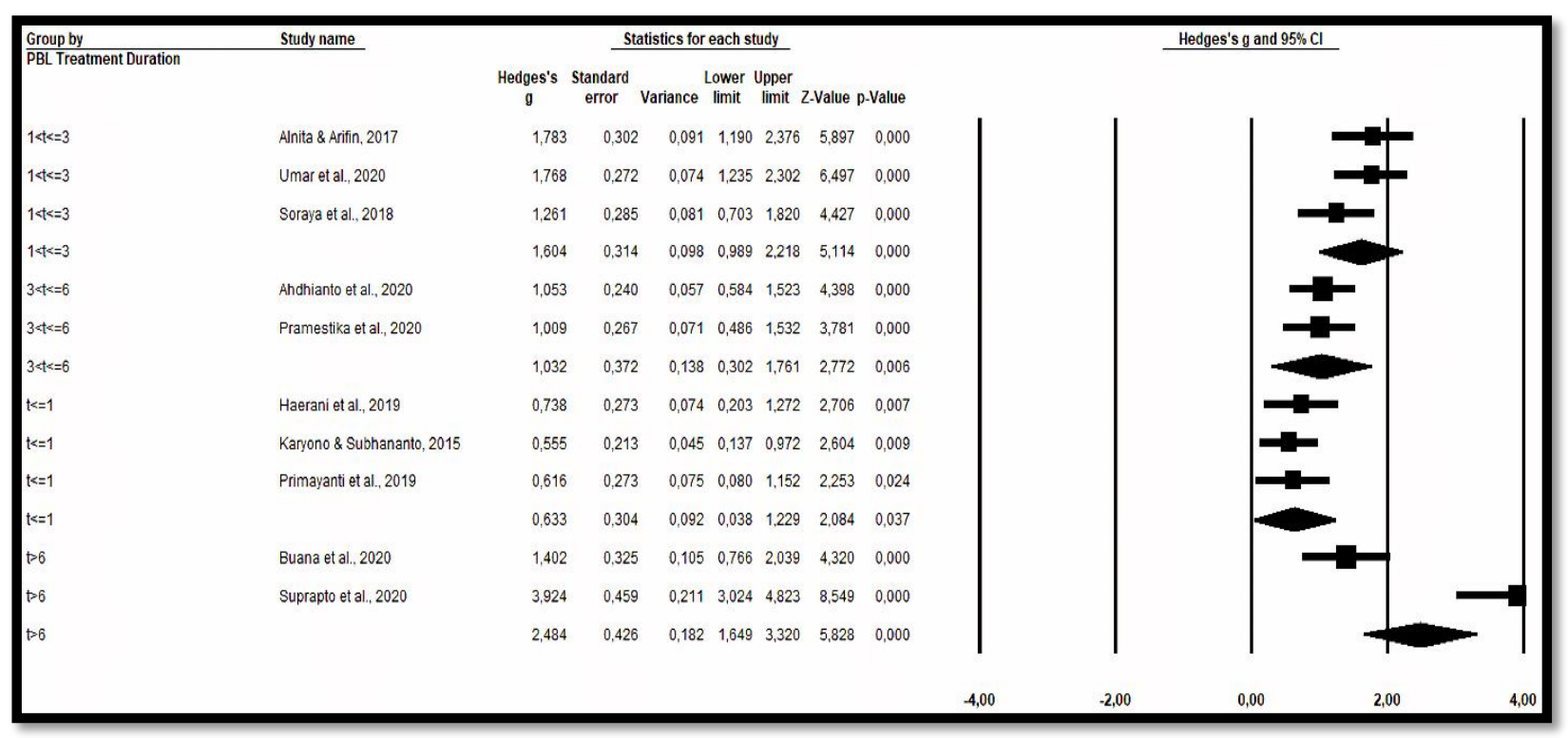

Figure 4. The Effect Size of PBL on the Primary Students' MCTS Based on PBL Treatment Duration

Figure 4 reveals that the effect size of PBL with a maximum treatment duration of 1 month on the students' MCTS was $\mathrm{g}=0.633$ and it was categorized as a moderate effect (Cohen et al., 2018). Meanwhile, other effect sizes of PBL on the students' MCTS based on PBL treatment duration were $\mathrm{g}=1.604$ (PBL with a maximum treatment duration of 3 months and a treatment duration of more than 1 month), $g=1.032$ (PBL with a maximum treatment duration of 6 months and a treatment duration of more than 3 months), and $g=2.484$ (PBL with a treatment duration of more than 6 months). These effect sizes were categorized as a strong effect (Cohen et al., 2018). In addition, every p-value of the $\mathrm{Z}$ statistic of PBL treatment duration groups was less than 0.05 . It interprets that the PBL implementation in every treatment duration category has a positive effect significantly on the primary students' MCTS. Dagyar \& Demirel (2015) also revealed that in every category of PBL treatment duration, the PBL implementation affected positively the students' mathematics achievement. It means that the implementation of PBL based on its treatment duration is effective to cultivate primary students' MCTS. The results of heterogeneity analysis based on the factor of PBL treatment duration are presented in Table 6. 
Nugraha, T., \& Suparman, S.

Table 6. The Results of the Q Cochrane Test of PBL Treatment Duration Factor

\begin{tabular}{|c|c|c|c|c|c|}
\hline \multirow{2}{*}{ PBL Treatment Duration } & \multirow{2}{*}{ Studies Number } & \multirow{2}{*}{ Hedge's g } & \multicolumn{3}{|c|}{ Heterogeneity Analysis } \\
\hline & & & Q-value & $\mathrm{df}(\mathrm{Q})$ & P-value \\
\hline $\mathrm{t} \leq 1$ month & 3 & 0.633 & \multirow{4}{*}{13.986} & \multirow{4}{*}{3} & \multirow{4}{*}{0.003} \\
\hline 1 month $<\mathrm{t} \leq 3$ months & 3 & 1.604 & & & \\
\hline 3 months $<\mathrm{t} \leq 6$ months & 2 & 1.032 & & & \\
\hline $\mathrm{t}>6$ months & 2 & 2.484 & & & \\
\hline
\end{tabular}

Note: $\mathrm{t}=$ treatment duration

Table 6 reveals that the p-value of the Q Cochrane statistic was less than 0.05 . It interprets that the factor of PBL treatment duration is one of the significant factors causing the heterogeneity of primary students' MCTS. Yunita et al. (2020) also found that PBL treatment duration was one of the significant factors affecting the heterogeneity of students' mathematical creative thinking skills. It means that the strong or moderate effect size of the PBL implementation on the primary students' MCTS is affected by the factor of PBL treatment duration. In addition, the effect of PBL on the students' MCTS tended to be stronger if its treatment duration was longer. Moreover, the effect size of PBL with a treatment duration of more than 6 months was stronger than the effect size of PBL with a maximum treatment duration of 6 months in cultivating primary students' MCTS. It interprets that the implementation of PBL with a treatment duration of more than 6 months is more effective than the implementation of PBL with a maximum treatment duration of 6 months in cultivating primary students' MCTS.

\section{Mathematics Topic}

The factor of mathematics topic consisted of three groups that were geometry, number, and statistics (Indonesian Minister of Education and Culture Regulation No. 21, 2016). Figure 5 reveals that the effect size of PBL on the students' MCTS in number topic was $g=1.171$ (strong effect). Moreover, the effect size of PBL on the students' MCTS in geometry topic was $g=2.295$ (strong effect). Meanwhile, the effect size of PBL on the students' MCTS in statistics topic was $\mathrm{g}=0.632$ (moderate effect) (Cohen et al., 2018). Also, every p-value of the $\mathrm{Z}$ statistic in every mathematics topic group was less than 0.05. These discoveries indicate that the PBL implementation in geometry, number, and statistics topic has positive effect significantly on the primary students' MCTS. Dagyar and Demirel (2015) also found that the implementation of PBL based on a scientific field such as natural sciences, mathematics, health sciences, social sciences, and computer sciences affected students' mathematics achievement positively. It interprets that to cultivate primary students' MCTS, the PBL implementation in geometry, numbers, and statistics topic is effective. The overall effect size of PBL on the students' MCTS based on mathematics topics is presented in Figure 5. 


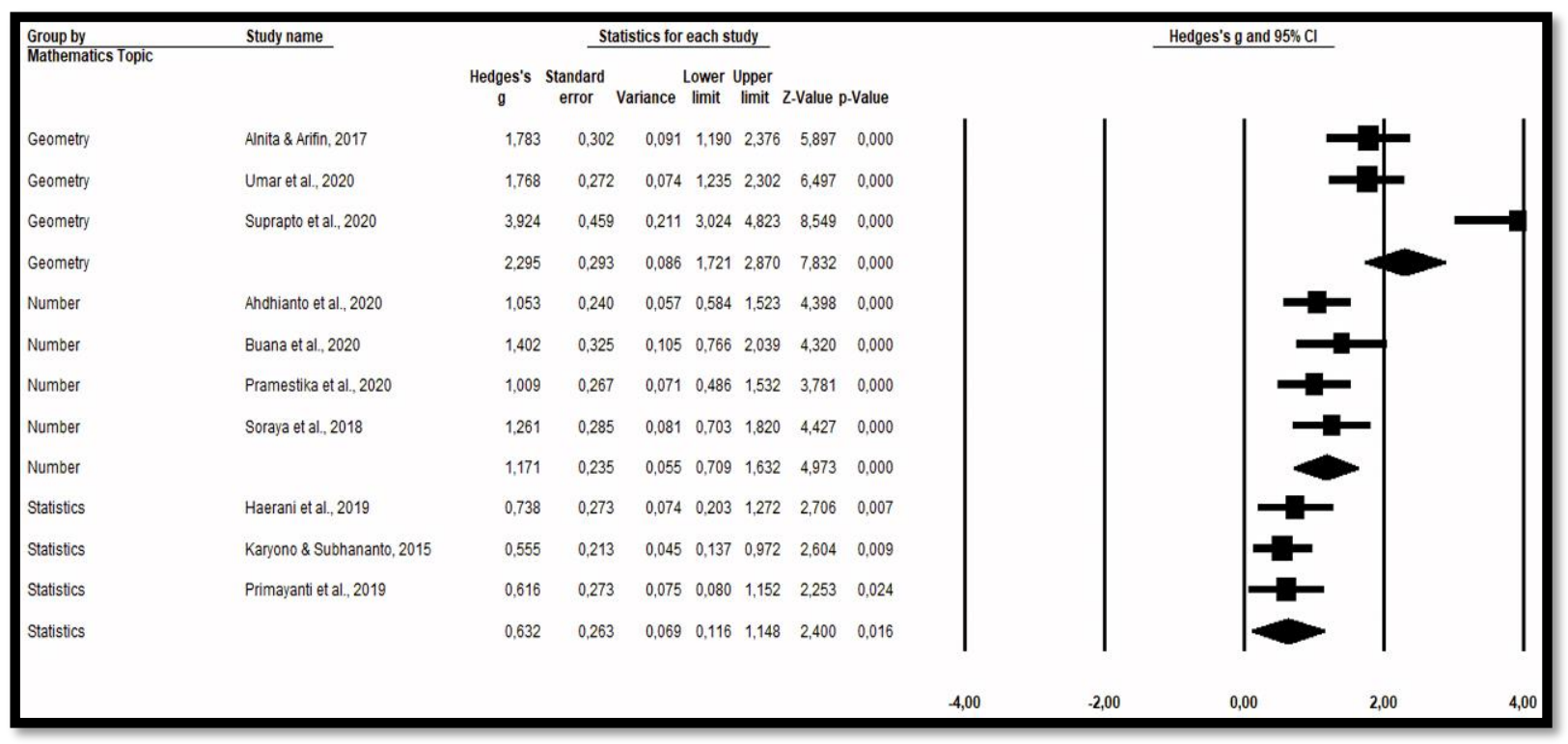

Figure 5. The Effect Size of PBL on the Primary Students' MCTS Based on Mathematics Topic

The results of heterogeneity analysis based on the factor of mathematics topic are presented in Table 7.

Table 7. The Results of the Q Cochrane Test of Mathematics Topic Factor

\begin{tabular}{lccccc}
\hline \multirow{2}{*}{ Mathematics Topic } & \multirow{2}{*}{ Studies Number } & \multirow{2}{*}{ Hedge's g } & \multicolumn{2}{c}{ Heterogeneity Analysis } \\
\cline { 5 - 6 } & 3 & 2.295 & Q-value & df(Q) & P-value \\
\hline Geometry & 4 & 1.171 & 18.267 & 2 & 0.000 \\
Number & 3 & 0.632 & & & \\
Statistics & & & & \\
\hline
\end{tabular}

Table 7 shows that the $\mathrm{p}$-value of the Q Cochrane statistic was less than 0.05 . It interprets that the mathematics topic is one of the significant factors affecting the heterogeneity of primary school students' MCTS through PBL. It means that the strong or moderate effect of PBL on the primary students' MCTS is caused by the factor of mathematics topic. Meanwhile, Dagyar and Demirel (2015) found that the factor of the scientific field did not cause the heterogeneity of students' mathematics achievement using PBL. These reports interpret that mathematics topics or scientific fields are not a significant causative factor consistently of the heterogeneous students' mathematics achievement that is specifically students' MCTS. In addition, the effect of PBL in geometry topic on the students' MCTS was stronger than the effect of PBL in number and statistic topic on the students' MCTS. It means that the implementation of PBL in geometry topic is more effective than the implementation of PBL in number and statistic topic on the primary students' MCTS.

\section{CONCLUSION AND SUGGESTION}

The synthesis of ten primary studies provides some information that the heterogeneity of primary students' MCTS through PBL is affected by some factors such as mathematics topic and PBL treatment duration. Meanwhile, PBL class capacity factor does not affect the heterogeneity of primary students' MCTS. Also, this research provides some information that the most effective PBL implementation in cultivating primary students' MCTS when it is implemented in the class with a maximum capacity of 28 students, on geometry topic, and with a treatment duration of more than six months. Therefore, this research suggests to mathematics teachers in primary 
school that they should implement PBL in the class with a maximum capacity of 28 students and with a treatment duration of more than six months. Also, they should improve their students' MCTS in other mathematics topics such as statistics topic by enhancing their effort in implementing PBL in the mathematics classroom. In addition, for further meta-analysis research regarding this topic, researchers should investigate and examine another potential causative factor of the heterogeneous primary students' MCTS through PBL such as research year, students' demography, students' prior mathematics skills, and professional and pedagogical mathematics teacher skill level.

\section{ACKNOWLEDGEMENT}

This research is supported financially by the Indonesian Endowment Fund of Education (LPDP).

\section{AUTHOR CONTRIBUTIONS STATEMENT}

$\mathrm{TN}$ and $\mathrm{S}$ conducted a joint analysis. They are looking for articles related to the impact of problem-based learning on critical thinking in elementary school students.

\section{REFERENCES}

Ahdhianto, E., Marsigit, M., Haryanto, H., \& Nurfauzi, Y. (2020). Improving fifth-grade students' mathematical problem-solving and critical thinking skills using problem-based learning. Universal Journal of Educational Research, 8(5), 2012-2021. https://doi.org/10.13189/ujer.2020.080539

Alnita, A., \& Arifin, R. R. M. (2017). Model pembelajaran berbasis masalah terhadap peningkatan kemampuan berpikir kritis matematis siswa kelas V sekolah dasar. Antologi UPI, 5(1), 178-186.

Apriyani, T. D., Fadiawati, N., \& Syamsuri, M. M. F. (2019). The effectiveness of problembased learning on the hoax information to improve students' critical thinking skills. International Journal of Chemistry Education Research, 3(1), 15-22. https://doi.org/10.20885/ijcer.vol3.iss1.art3

Bernard, R. M., Borokhovski, E., Schmid, R. F., Tamim, R. M., \& Abrami, P. C. (2014). A metaanalysis of blended learning and technology use in higher education: From the general to the applied. Journal of Computing in Higher Education, 26(1), 87-122. https://doi.org/10.1007/s12528-013-9077-3

Borenstein, M., Hedges, L. V., Higgins, J. P. T., \& Rothstein, H. R. (2009). Introduction to metaanalysis. John Willey and Son Ltd. https://doi.org/10.1007/978-3-319-14908-0_2

Buana, I. M. E. T., Astawan, I. G., \& Japa, I. G. N. (2020). Improving students' creative thinking skill in mathematics through PBL based on Catur Pramana by controlling students' numeric skill. Jurnal Ilmiah Sekolah Dasar, 4(3), 440-448. https://doi.org/10.23887/jisd.v4i3.25984

Cohen, L., Manion, L., \& Morrison, K. (2018). Research Methods in Education (8th ed.). Routledge Taylor \& Francis Group.

Cooper, H. M., Patall, E. A., \& Lindsay, J. J. (2013). Research synthesis and meta-analysis. In L. Bickman \& D. J. Rog (Eds.), The SAGE handbook of applied social research methods (pp. 344-370). Sage Inc. https://doi.org/https://dx.doi.org/10.4135/9781483348858 
Dałyar, M., \& Demirel, M. (2015). Effects of problem-based learning on academic achievement: A meta-analysis study. Education and Science, 40(181), 139-174. https://doi.org/10.15390/EB.2015.4429

Du, X., Emmersen, J., Toft, E., \& Sun, B. (2013). PBL and critical thinking disposition in Chinese medical students - a randomized cross-sectional stu. Journal of Problem Based Learning in Higher Education, 1(1), 72-83. https://doi.org/10.5278/ojs.jpblhe.v1i1.275

Epafras, L. C., Djalong, F. A., \& Kaunang, H. P. (2019). Beyond signal and noise: Academics goes hoax and hoaxtivism. Kawistara, 8(3), 213-309. https://doi.org/10.22146/kawistara.34646

Haerani, I., Winarti, W., \& Muftianti, A. (2019). Meningkatkan kemampuan berpikir kritis siswa sekolah dasar kelas IV dalam mata pelajaran matematika melalui model problem based learning. COLLASE (Creative of Learning Students Elementary Education), 2(1), 26-32.

Higgins, J. P. T., Thompson, S. G., Deeks, J. J., \& Altman, D. G. (2003). Measuring inconsistency in meta-analysis. British Medical Journal, 327, 557-560. https://doi.org/10.1007/s10844-006-2974-4

Karyono, K., \& Subhananto, A. (2015). Keefektifan problem-based learning untuk meningkatkan kemampuan kritis matematis siswa sekolah dasar. Jurnal Tunas Bangsa, 2(1), 72-84.

Liberati, A., Altman, D. G., Tetzlaff, J., Mulrow, C., Gøtzsche, P. C., Ioannidis, J. P. A., Clarke, M., Devereaux, P. J., Kleijnen, J., \& Moher, D. (2009). The PRISMA statement for reporting systematic reviews and meta-analyses of studies that evaluate health care interventions: Explanation and elaboration. In Journal of Clinical Epidemiology (Vol. 62, Issue 10). https://doi.org/10.1016/j.jclinepi.2009.06.006

Lipsey, M. W., \& Wilson, D. (2001). Applied social research methods series. Sage Publications Inc. https://psycnet.apa.org/record/2000-16602-000

McHugh, M. L. (2012). Interrater reliability: The kappa statistic. Biochemica Medica, 22(3), 276-282. https://hrcak.srce.hr/89395

Nargundkar, S., Samaddar, S., \& Mukhopadhyay, S. (2014). A guided problem-based learning (PBL) approach: Impact on critical thinking. Decision Sciences Journal of Innovative Education, 12(2), 91-108. https://doi.org/10.1111/dsji.12030

Neber, H., \& Neuhaus, B. J. (2013). Creativity and problem-based learning (PBL): A neglected relation. In Creativity, talent and excellence (pp. 43-56). Springer. https://doi.org/10.1007/978-981-4021-93-7

Pramestika, N. P. D., Wulandari, I. G. A. A., \& Sujana, I. W. (2020). Enhancement of mathematics critical thinking skills through problem-based learning assisted with concrete media. Journal of Education Technology, 4(3), 254-263. https://doi.org/10.23887/jet.v4i3.25552

Primayanti, P. E., Suarjana, I. M., \& Astawan, I. G. (2019). Pengaruh model PBL bermuatan kearifan lokal terhadap sikap sosial dan kemampuan berpikir kritis matematika siswa kelas V di gugus V Kecamatan Sukasada. Journal of Education Technology, 3(1), 28-34. https://doi.org/10.23887/tscj.v1i2.20417

Rothstein, H. R., Sutton, A. J., \& Borenstein, M. (2005). Publication bias in meta-analysis: Prevention, assessment and adjustments. John Willey and Son Ltd. 
https://doi.org/10.1002/0470870168

Sanabria, J. C., \& Arámburo-Lizárraga, J. (2017). Enhancing 21st century skills with AR: Using the gradual immersion method to develop collaborative creativity. Eurasia Journal of Mathematics, Science and Technology Education, 13(2), 487-501. https://doi.org/10.12973/eurasia.2017.00627a

Sanders, S. (2016). Critical and creative thinkers in mathematics classrooms. Journal of Student Engagement: $\quad$ Education Matters, 6(1), 19-27. https://ro.uow.edu.au/cgi/viewcontent.cgi?article=1043\&context=jseem\&httpsredir=1\&ref erer $=$

Silber-Varod, V., Eshet-Alkalai, Y., \& Geri, N. (2019). Tracing research trends of 21st-century learning skills. British Journal of Educational Technology, 50(6), 1-20. https://doi.org/10.1111/bjet.12753

Soraya, D., Jampel, I. N., \& Diputra, K. S. (2018). Pengaruh model pembelajaran problem based learning (PBL) berbasis kearifan lokal terhadap sikap sosial dan berfikir kritis pada mata pelajaran matematika. Thinking Skills and Creativity Journal, 1(2), 76-85. https://doi.org/10.23887/tscj.v1i2.20409

Suparman, Juandi, D., \& Tamur, M. (2021a). Problem-based learning for mathematical critical thinking skills: A meta-analysis. Journal of Hunan University (Natural Sciences), 48(2), 133-144.

Suparman, Juandi, D., \& Tamur, M. (2021b). Review of problem-based learning trends in 20102020: A meta-analysis study of the effect of problem-based learning in enhancing mathematical problem-solving skills of Indonesian students. Journal of Physics: Conference Series, 1722(012103), 1-9. https://doi.org/10.1088/1742-6596/1722/1/012103

Suparman, Juandi, D., \& Tamur, M. (2021c). Does problem-based learning enhance students' higher order thinking skills in mathematics learning? A systematic review and metaanalysis. The 4th International Conference on Big Data and Education, 44-51. https://doi.org/https://doi.org/10.1145/3451400.3451408

Suparman, S., Juandi, D., \& Herman, T. (2021). Achievement emotions of female students in mathematical problem-solving situations. Journal of Physics: Conference Series, 1806(1), 1-7. https://doi.org/10.1088/1742-6596/1806/1/012106

Suparman, Tamur, M., Yunita, Wijaya, T. T., \& Syaharuddin. (2021). Using problem-based learning to enhance mathematical abilities of primary school students : A systematic review and meta-analysis. JTAM (Jurnal Teori Dan Aplikasi Matematika), 5(1), 144-161. https://doi.org/https://doi.org/10.31764/jtam.v5i1.3806

Suparman, Yohannes, \& Arifin, N. (2021). Enhancing mathematical problem-solving skills of Indonesian junior high school students through problem-based learning: A systematic review and meta-analysis. Al-Jabar: Jurnal Pendidikan Matematika, 12(1), 1-16.

Suprapto, A., Ambarita, A., \& Caswita. (2020). The effectiveness of learning design based on problem-based learning model oriented mathematical critical thinking skills of fifth grade in elementary school. Journal of Education and Practice, 11(27), 95-100. https://doi.org/10.7176/jep/11-27-11

Umar, U., Kaharuddin, A., Fauzi, A., Widodo, A., Radiusman, R., \& Erfan, M. (2020). A comparative study on critical thinking of mathematical problem-solving using problem - 
based learning and direct intruction. The 1st Annual Conference on Education and Social Science (ACCESS) 2019, 465, 314-316. https://doi.org/10.2991/assehr.k.200827.079

Vevea, J. L., Zelinsky, N. A. M., \& Orwin, R. G. (2019). Evaluating coding decisions. In The handbook of research synthesis and meta-analysis (3rd ed., pp. 174-201). Russel Sage Foundation. https://doi.org/https://doi.org/10.7758/9781610448864

Yew, E. H. J., \& Goh, K. (2016). Problem-based learning: An overview of its process and impact on learning. Health Professions Education, 2(2), 75-79. https://doi.org/10.1016/j.hpe.2016.01.004

Yohannes, Juandi, D., \& Diana, N. (2020). The evaluation of problem-based learning model towards high school students' critical thinking skills: A meta-analysis study in Indonesia. The 12th International Conference on Education Technology and Computers, 199-204. https://doi.org/https://doi.org/10.1145/3436756.3437045

Yunita, Y., Juandi, D., Tamur, M., Adem, A. M. G., \& Pereira, J. (2020). A meta-analysis of the effects of problem-based learning on students' creative thinking in mathematics. Beta: Jurnal Tadris Matematika, 13(2), 104-116. https://doi.org/10.20414/betajtm.v13i2.380 